\title{
Genetic Diversity of Growth Hormone Genes and Its Relationship with Weight Coast Gain of Pesisir Cattle
}

Mangku Mundana ${ }^{*}$, Sarbaini, Yurnalis and Jaswandi

Faculty of Animal Science, Andalas University, Padang West Sumatra, Indonesia

DOI: $10.36347 /$ sjavs.2020.v07i10.001

| Received: 04.10.2020 | Accepted: 20.10.2020 | Published: 26.10 .2020

*Corresponding author: Mangku Mundana

\section{Abstract}

Original Research Article

This study aimed to: 1) Obtain diversity of body weight gain in Coastal cows, 2) Obtain diversity of growth hormone genes $(\mathrm{GH})$ in intron 3 to exon $4(\mathrm{GH} 4)$ and intron 4 to exon 5 (GH5) in Coastal cattle using the polymerase method chain reaction-restriction fragment length polymorphisms (PCR-RFLP), 3) Obtain a relationship between diversity of growth hormone genes (GH4 and GH5) with body weight gain in Coastal cows. This research was conducted in the field and in the laboratory. Field research was conducted to obtain data on body weight gain and blood samples from Coastal cows. Samples used amounted to 141 Coastal cows with age around 1-4 years where Coastal cows came from Ranah Pesisir District and Bayang District in Pesisir Selatan Regency, West Sumatra Laboratory research was conducted at the Laboratory of Animal Biotechnology, Faculty of Animal Husbandry, Andalas University. The diversity of the GH gene was determined by gene frequency, heterosigosity values, the value of Polymorphic Informative Content (PIC), gene balance in the population, and the relationship between the diversity of GH genes with body weight gain in Coastal cattle. The results of the field research showed that the average body weight of Male Coastal cattle was $0.142 \pm 0.086 \mathrm{~kg}$ or $142 \mathrm{gr} / \mathrm{cow} /$ day with a high coefficient of diversity that was $20.4 \%$ and on CoastalFemale cows $0.195 \pm 0.153 \mathrm{~kg}$ or $195 \mathrm{gr} / \mathrm{cow} /$ day with a coefficient diversity of $73.3 \%$. Laboratory research results obtained the diversity of GH (polymorphic) genes in the GH4 | AluI gene and the GH5 | Eco471 gene. Genotype frequency of GH4 gene fragments Gene AluI is AA of 0.79 and BB of 0.21 and allele frequencies (A) and (B) for GH4 | AluI are 0.79 and 0.21, and for GH5 | Eco471 genotype frequencies are TT, TC, and CC respectively according to $0.52,0.34$, and 0.14 while the allele frequencies were $\mathrm{T}$ alleles 0.69 and $\mathrm{C} 0.31$. The observed Heterozygosity values and expectations of GH4 | AluI and GH5Eco471 were 0.00, 0.34 and 0.334, 0.323. For the PIC value of GH4 AluI and GH5 Eco471 obtained respectively 0.39, and 0.51. The results of the General Lineir Model analysis did not reveal a relationship of diversity between the GH4 and GH5 genes with body weight gain in Coastal cattle. The conclusions of this study are: (1) The diversity of body weight gain in the Coastal Cattle Coastal cow is higher than the Male Coastal cattle; (2) There is genetic (polymorphic) diversity in the GH4 | AluI and GH5 | Eco471 genes in Coastal cattle; (3) There is no significant relationship (P>0.05) between the GH4 and GH5 growth hormone genes with body weight gain in Coastal cow.

Keywords: Coastal Cows, Body Weight Gain, Growth Hormone Gene (GH), PCR-RFLP, heterosigosity, polymorphic informative content (PIC).

Copyright $\odot 2020$ The Author(s): This is an open-access article distributed under the terms of the Creative Commons Attribution 4.0 International License (CC BY-NC 4.0) which permits unrestricted use, distribution, and reproduction in any medium for non-commercial use provided the original author and source are credited.

\section{INTRODUCTION}

Pesisir cattle as genetic resources (source of germplasm) are widely maintained in the South Coast region of West Sumatra. Generally, maintenance of Coastal cow is still widely maintained extensively where the cows are released just like that and relatively little attention of breeders in maintenance, so that the productivity of these cows has not reached maximum results. According to [1] Coastal cows have good genetic potential because they have a high adaptability to both low quality feed, and to changes in environmental temperature so that
These coastal cows are relatively smaller in size compared to other types of local cow such as PeranakanOngole cows (PO cows), Bali cows, Madura cows. Even though the body size is classified as small, this cow has a fairly high percentage of carcasses according to [1] the percentage of carcasses of Coastal cow was $50.6 \%$, while according to [2] Coastal cows given $75 \%$ concentrate plus $25 \%$ ammoniation straw percentage $53 \%$. This percentage of carcass was higher than the percentage of carcasses of Ongole cattle $(48.8 \%)$, Madura cattle $(47.2 \%)$, PO cows $(45 \%)$ and Buffalo (39.3\%), but slightly lower when compared to 
carcasses Bali cattle (56.9\%). A fairly high percentage of carcasses indicates the ability of Coastal Cows as "factories" producing meat to meet the needs of animal protein because it is able to convert forage (grass) which is relatively low quality into high-quality meat for human consumption, so Coastal cows has the potential to be developed.

If seen from the selection effort carried out by farmers, the selection is negative in nature, where there is a tendency for farmers to sell cows with higher body weight to get higher prices. So that the cows that are still being raised by breeders are cows with smaller body weight, for this reason it is necessary for government efforts, especially the Animal Husbandry Department, to maintain the presence of Coastal Cow whose best performance is to be used as superior breeds. With the superior Coastal cattle service, the quality of Coastal cattle can always be maintained and improved so that their productivity will also increase.

Based on PCR-RFLP data, the GH gene is known to have a high diversity [39]. Several studies have been conducted relating to the growth hormone (GH) gene has been widely reported [3-6], who stated that there were polymorphisms found in bovine growth hormone $(\mathrm{GH})$ genes in intron 3 to 3 exon 5 . Furthermore [7], from the results of his research concluded that Coastal cattle have a high diversity in which of the 4 fragments studied were found 18 lesions, 15 insertions and 21 mutations in which 16 lesions, 12 insertions and 19 mutassi among them are new mutations that are not yet found in the GH gene that is digen Bank. Furthermore [7], that out of 18 dilutions, 15 insertions and 21 mutations there were 10 lesions, 4 insertions, and 17 mutations are polymorphic so that they have the potential to be genetic markers and can be further tested to be candidate markers.

Several studies had found that the polymorphism has a positive effect on the nature of body weight and quality of meat [8-10], associated with feed consumption, growth / body condition [11] is associated with growth and quality of carcasses in cattle [12] and as a sign in the selection of carcass and meat traits in Bos Taurus-Bos indicus cattle [13].

Based on the description above, it is necessary to conduct research to identify genetic diversity of the growth hormone $(\mathrm{GH})$ genes of Coastal cattle in intron 3 to exon 4 , and intron 4 to exon 5 regions which have not been much explored, as well as their relationship with body weight gain. This is very important to be investigated as an effort to improve livestock breeding programs based on the results of research in the field of molecular biotechnology.

\section{MATERIALS AND METHOD Research Methodology \\ Sampling of Cattle}

Sampling of cattle was carried out by sampling authority [14] with the criteria for cattle are Coastal cows in Ranah Pesisir District and in Kambang District, South Coastal Regency. The selection of research sites, namely Ranah Pesisir and Kambang Districts was based on the assumption that the cows in this district were still not mixed with other types of blood. The selected sample of cows was 1-4 years old with male and female sex. The number of coastal cattle samples taken in this study was 141 animals.

\section{Weighing}

Weighing was done in the morning before cows were fed or released into the pasture. Weighing was done twice with different time intervals namely 71 days, 65 days, 64 days and 59 days. Weighing was done using a digital weighing device with a capacity of 400 $\mathrm{kg}$.

\section{Sampling of Blood}

Blood sampling in cows was done through the jugolaris vein and / or coccige vein using a venoject tube. The number of blood samples taken was 3 to $5 \mathrm{ml}$ per cow. Then the blood sample was put into a coolbox and taken to the laboratory, and stored in a freezer with a temperature of $-20 \cdot \mathrm{C}$.

\section{Observed Variables}

The variables observed and measured in this field study were body weight gain of each cow in $\mathrm{kg}$ units. Coastal cattle body weight gain was obtained from the results of weighing cattle twice in a certain time interval. In this study the time interval was 71 days, 65 days, 64 days and 59 days.

\section{Data Analysis}

The weight gain data of each cow that obtained was analyzed using descriptive statistics to obtain the average value, standard deviation and coefficient of variance [15] with the following formula:

1) Average Score :

$$
\bar{x}=\frac{\sum_{i=1}^{n} x_{i}}{n}
$$

2) Standard Deviation :

$$
S=\sqrt{\frac{\sum_{i=1}^{n} f_{i}\left(x_{i}-\bar{x}\right)^{2}}{n-1}}
$$

3) variance coefficient:

$$
K K=\frac{S}{\bar{x}} \times 100
$$


Description:

S: Standard Deviation

$\mathrm{KK}$ : variance coefficient

xi: I-size, $\mathrm{x}$-variable

$\mathrm{n}$; the number of sample

\section{Total DNA Isolation}

Materials and tools used for total DNA isolation were: the Protocol Genomic DNA Purificationation Kit from Promega. Macro pipette 200 P, 1000 P Gibson, TR222Y axygen tip pipette, T1000B, $1.5 \mathrm{ml}$ eppendorfmicrotube size, eppendorf brand 5415C microsentrifuge, waterbath, vortex (maxi mix), and vacuum dryer oven. Isolation of total DNA from cow blood samples was carried out using the Genomic DNA Purification Kit protocol from Promega. The working procedure is as follows:

1) $300 \mu \mathrm{l}$ blood sample mixed with $900 \mu \mathrm{l}$ of lysis cell solution $(0.32 \mathrm{M}$ sucrose, $1 \% \mathrm{v} / \mathrm{v}$ triton X-100.5 $\mathrm{mM} \mathrm{MgCI} 2,10 \mathrm{mM}$ Tris-HCI pH 7.4) in a $1.5 \mathrm{ml}$ eppendorf tube.

2) The mixture was stirred evenly by flipping the tubes 5-6 times. The mixture was incubated at room temperature for 10 minutes (alternating tubes 2-3 times during incubation).

3) The solution was centrifuged at a speed of $14,000 \mathrm{~g}$ for 20 seconds.

4) The formed supernatant was removed.

5) Tube containing the divortex precipitate for 2-3 minutes, add $300 \mu 1$ of Nuclei Lysis solution, dropdown liquid pipette so that the precipitate dissolves and incubation at $37 \mathrm{oC}$ for 1 hour.

6) Protein precipitating solution (Protein Precipitation) was added as much as $200 \mu$ l into the tube and a muddy precipitate will be formed then centrifuged at a speed of 14,000 $\mathrm{g}$ for 3 minutes.

7) Supernatant pipette and transfer to a new sterile eppendorf tube $(1.5 \mathrm{ml}$ size $)$ and add $150 \mu \mathrm{l}$ isopropanol.

8) The tube is turned upside down to mix the solution until a material such as white thread (DNA) is formed.

9) This mixture was then centrifuged at a speed of $14,000 \mathrm{~g}$ for 1 minute.

10) Supernatant was pipetted and discarded, then add $300 \mu \mathrm{l}$ of $70 \%$ ethanol.

11) The tube containing the solution was then alternated to wash DNA, then centrifuged at a speed of 14,000 $\mathrm{g}$ for 30 seconds.
12) Ethanol was pipetted / carefully disposed of the tube behind on the surface of the tissue and left open for 10-15 minutes to dry the DNA.

13) To the tube containing DNA deposition 50-100 $\mu 1$ of rehydration solution is added.

14) The obtained DNA was stored in a freezer at a temperature $\left(-20^{\circ} \mathrm{C}\right)$ and ready for use for various analyzes.

15) The concentration of DNA obtained will vary greatly $(50-400 \mathrm{ng} / \mu \mathrm{l})$, because it is influenced by how much the cell nucleus undergoes lysis. To determine the concentration of DNA from isolation, it is estimated by comparing it with standard DNA (DNA $10 \quad \mathrm{ng} / \mu \mathrm{l}$ ) using electrophoresis, then visualizing it with a UV transluminator.

\section{Visualization of Isolated DNA}

Visualization of isolated DNA was carried out using $1.5 \%$ agarose gel electrophoresis with the following procedure:

1) Make a mixed solution of $1.5 \%$ satellite agar with 1X TBE $(50 \mathrm{ml}$ TBE added $950 \mathrm{ml}$ of distilled water).

2) Heat the hot plate stirrer until it boils (the solution looks clear).

3) Cool to a temperature of about $60 \cdot \mathrm{C}$.

4) Add $5 \mu 1$ of ethidium bromide.

5) Pour the solution so that the accidental prepared by placing the comb in accordance with the number of samples needed and allow it to freeze.

6) Put the mold into the Electrophresis submarine which contains $1 \mathrm{X}$ TBE solution.

7) Remove the comb from its place and insert the sample to be visualized into the comb's well.

8) Submarine Electrophoresis is ready to run with a voltage regulation of 200 volts in 45-60 minutes.

9) Then agarose gel is inserted into the Gel Doc that has been connected with a computer and monitor, the photos are stored on disk or flash and printed.

10) If the photo shows visible bands, then this indicates the presence of DNA samples.

\section{Amplification of GH Gen Fragment}

Amplification of GH gene fragments was done by using two pairs of primers which are expected to be able to amplify the growth hormone gene according to the target. The primers used are presented in Table- 1 .

Table-1: Primary Sequences Used For Pcr Of Coastal Cow Gh Genes

\begin{tabular}{|l|l|l|l|}
\hline Fragment & Primary sequences & Location & Length (bp) \\
\hline GH4F & 5'- GGA TGG CAG TGG AGG ATG AT -3' & $1588 / 2186$ & 599 \\
GH4R & 5'- AGG TCT GCT TGA GGA TCT GC -3' & & \\
GH5F & 5'- CTT CGG CCT CTC TGT CTC TC -3' & $2105 / 2694$ & 590 \\
GH5R & 5'-CTT CGG CCT CTC TGT CTC TC -3' & & \\
\hline
\end{tabular}

The procedure for PCR amplification using DreamTag Green PCR Master Mix (2X) is as follows:
1) Make a $25 \mu \mathrm{l}$ PCR solution with the following composition: genome DNA $3 \mu \mathrm{l}$, primary $3 \mu \mathrm{l}$, Master Mix $5 \mu$, Nutrient Free Water (NFW) 14 
$\mu \mathrm{l}$, and for a volume of $50 \mu \mathrm{l}$ the composition of genome DNA was $3 \mu \mathrm{l}$, Primary $3 \mu \mathrm{l}$, Master Mix $10 \mu \mathrm{l}$, NFW $34 \mu \mathrm{l}$,

2) Amplification is done by initial denaturation of 95 • $\mathrm{C}$ for 5 minutes, $95 \cdot \mathrm{C}$ for 30 seconds, $58 \cdot \mathrm{C}$ for 30 seconds and $72 \cdot \mathrm{C}$ for 50 seconds and as many as 34 replications or cycles are continued $72 \cdot \mathrm{C}$ for 5 minutes.

3) To see the results of the amplification, electrophoresis was carried out with satellite agar or $1-2 \%$ agarose stained with ethidium bromide. Next will be seen the bands that form on each well containing DNA samples from PCR.

4) Determination of the size of each band formed on the gel is done by comparing the position of the tape with the position of the DNA ladder band (DNA marker). Next the DNA band that appears photographed with UV camera.

\section{Restriction Analysis}

Restriction analysis was carried out on the GH gene amplification results using four types of restriction enzymes, namely AluI and Eco 471 with the characteristics of each enzyme as in Table-2.

Table 2: Characteristics of Alul Restriction Enzyme, Eco 471

Enzyme Recognized Sequence Fragment ${ }^{\circ} \mathrm{C}$ incubation

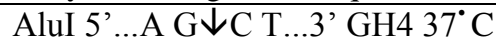

Eco $4715^{\prime}$...G $\downarrow$ GWCC GH5 $37^{\circ} \mathrm{C}$

The restriction analysis procedure is as follows:

1) Make a retention solution using AluI and Eco 471 enzymes by mixing each PCR product, $10 \mu \mathrm{l}$ samples are added, $20 \mu 1$ restriction enzyme mixture consisting of 1-2 $\mu 1$ restriction enzymes, $2 \mu$ l buffer and 18 Nuclease Free Water (NFW).

2) Incubate the material into the water incubator at $37^{\circ}$ C for about 4 - 5 hours.

3) The incubated material is then electrophoresed.

4) Electrophoresis results are inserted into the geldok and observed on the monitor screen.

5) Do pengotototkan based on the ribbons formed.

\section{Genotype}

The electrophoresis results seen on the monitor screen were carried out by genotype based on:

1) The difference in the position of the bands if the results of the electrophoresis obtained the same number of bands that is 2 bands but there are different positions as in the diversity of the AluI GH4 gene where the genotypes obtained are AA and BB.

2) Types of ribbon patterns and their different positions. There are two kinds of ribbon patterns that are formed, namely 2 and 3 ribbon patterns, and 3 different ribbon pattern positions. For example in the diversity of the GH5 Eco 471 gene, where the TT genotype with 2 banding patterns, TC and CC are both 3 banding patterns but there are differences in position on one ribbon.

\section{Observed Variables}

The observed variables related to the diversity of the GH4 and GH5 genes were (1). Genotype frequency, (2).Allele frequency, (3).Heterozygosity, (4) Polymorphic Informative Content (PIC), (5) Hardy Weinberg Balance, and (6) Relationship of GH gene genotype diversity with body weight gain in Coastal cows.

\section{Data Analysis \\ Genotype Frequency}

The genotype frequency is calculated by comparing the number of genotype individuals with individual samples in the population with the following equation:

$$
\chi_{i i}=\frac{n_{i i}}{n}
$$

\section{Alel Frequency}

Allele frequency is the ratio of an allele to all alleles at a locus in the population. The mathematical model of the genotype frequency [16] is denoted as follows:

$$
\chi_{i}=\left(2 n_{i i}+\sum_{j \neq i} n_{i j}\right) /(2 n)
$$

Description:

$\chi_{\mathrm{i}}=\mathrm{I}$-thalel frequency

$\mathrm{n}_{\mathrm{i} i}=$ The number of I-thhomozigot individual

$\mathrm{n}_{\mathrm{ij}}=$ the number of heterozygote

$\mathrm{n}=$ the number of sample

$\chi \mathrm{i}=\mathrm{I}$-thalel frequency

\section{Heterozigositas}

Estimation of the value of observed heterozygosity (Ho) and heterozygosity of expectations (He) is calculated using the formula $[17,18]$ as follows:

Ho $=\sum_{i \neq j} \frac{n_{i j}}{N}$

Description:

$\mathrm{H}_{\mathrm{o}}=$ Heterozygosity observation frequency

$\mathrm{n}_{\mathrm{ij}}=$ the number of heterozygot at 1 -st locus

$\mathrm{N}=$ the number of analyzed individual

He $=1-\sum_{i=1}^{q} p 1 i^{2}$

Description:

$\mathrm{H}_{\mathrm{e}}=$ frequency of heterozygosity of expectations

$\mathrm{p} 1 \mathrm{i}=$ frequency of 1 stalel at 1 st locus $\mathrm{q}=$ the number of alel at 1 st locus 


\section{Polymorphic Informative Content (PIC)}

The informative level of an allele was calculated according to [19] with the formula;

$$
P I C=1-\sum_{l=1}^{N} P_{i}^{2}-\sum_{i=1}^{n-1} \sum_{j=i+1}^{n} 2 P_{1}^{2} P_{j}^{2}
$$

Description

$\mathrm{P}_{\mathrm{i}=\mathrm{I}}$-stalel frequency

$\mathrm{n}=$ the number of alel per-marker

\section{Analysis of Relationship of GH Genotypevariance with Growth of Pesisir Cow Body Weight}

The relationship of $\mathrm{GH}$ gene diversity with body weight gain of Coastal cow using General Lineir Model analysis with statistical models [20] are as follows:

$Y_{i j}=\mu+\alpha i+\beta j+G_{i}+E_{i j}$
Description:

$\mathrm{Y}_{\mathrm{ij}}=$ Observation score because of I-th genotype influence

$\mu=$ Mean

$\alpha i=$ Influence of gender

$\beta \mathrm{j}=$ Influence of age

$\mathrm{Gi}=$ Influence of I-th genotype

$E_{i j}=$ Influence of trial error

Analysis of the relationship of $\mathrm{GH}$ gene genotype diversity with body weight gain used the "SAS" program.

\section{RESULTS AND DISCUSSION \\ Variance of Body Weight Gain of Pesisir Cows}

The diversity of Coastal cow body weight gain can be seen from the average data, standard deviation, and coefficients of the variation in body weight of the Coastal cow aged 1-4 years obtained in this study can be seen in Table- 3 .

Table 3: Average Body Weight Gain (ADG), Standard Deviation, And Coefficient of Diversity of Male Andfemale Coastal Cows at the Age of 1-4 Years

\begin{tabular}{|c|c|c|c|c|c|}
\hline $\begin{array}{l}\text { The number } \\
\text { of cows }\end{array}$ & $\begin{array}{l}\text { Eger } \\
\text { (year) }\end{array}$ & Gender (Male/Female) & $\begin{array}{l}\text { ADG } \\
\text { (kg/day) }\end{array}$ & $\begin{array}{l}\text { Standard } \\
\text { Deviation (SD) }\end{array}$ & $\begin{array}{l}\text { Variance } \\
\text { Coefficient }\end{array}$ \\
\hline \multirow[t]{2}{*}{141} & \multirow[t]{2}{*}{1} & Male & 0,155 & 0,146 & 0,946 \\
\hline & & Female & 0,177 & 0,137 & 0,774 \\
\hline \multirow[t]{2}{*}{141} & \multirow[t]{2}{*}{2} & Male & 0,071 & 0,070 & 0,988 \\
\hline & & Female & 0,083 & 0,035 & 0,421 \\
\hline \multirow[t]{2}{*}{141} & \multirow[t]{2}{*}{3} & Male & 0,197 & 0,042 & 0,212 \\
\hline & & Female & 0,220 & 0,220 & 1,000 \\
\hline \multirow[t]{2}{*}{141} & \multirow[t]{2}{*}{4} & Male & 0,144 & 0,087 & 0,605 \\
\hline & & Female & 0,300 & 0,221 & 0,736 \\
\hline \multirow[t]{2}{*}{ Total } & \multicolumn{2}{|l|}{ Male } & 0,567 & 0,345 & 0,817 \\
\hline & \multicolumn{2}{|l|}{ Female } & 0,780 & 0,613 & 2,931 \\
\hline \multirow[t]{2}{*}{ Average } & \multicolumn{2}{|l|}{ Male } & 0,142 & 0,086 & 0,204 \\
\hline & \multicolumn{2}{|l|}{ Female } & 0,195 & 0,153 & 0,733 \\
\hline
\end{tabular}

In Table-3 it can be stated that the average body weight gain (AVG / Average Daily Gain) Male Coastal cattle age 1-4 years obtained by $0.142 \mathrm{~kg}$ or 142 gr / cow / day, and on the coast of the Virgin Coastal average body weight gain 1-4 years old obtained 0.195 or $195 \mathrm{gr} / \mathrm{cow} / \mathrm{day}$. If the AVG value obtained in this study is compared with the AVG value of Coastal cows from [1] at the age of 3-4 years in the Male and African Coastal cows each $0.12 \mathrm{~kg} / \mathrm{day}$, the results of this study are higher. However, when compared with the results of research by [21] where body weight gain was $238 \mathrm{gr} / \mathrm{cow} / \mathrm{day}$, the results obtained were lower. This difference is due to the different types of rations given in the research of [21], namely the ration of $10 \mathrm{~kg}$ of natural grass, $1.4 \mathrm{~kg}$ of bran, $2.2 \mathrm{~kg}$ of sago and $1.2 \mathrm{~kg}$ of banana stems, whereas breeders in general only release his cattle in the pasture fields. If the results of this study are compared with the results of the research of [22] in which the weight gain of Coastal cattle is 0.1 $-0.3 \mathrm{~kg} / \mathrm{cow} / \mathrm{day}$, the results of this study are almost the same, namely $0.071-0.3 \mathrm{~kg} / \mathrm{cow} / \mathrm{day}$.
The coefficient of diversity values obtained in Male cattle was $20.40 \%$ and in Bulgaria was $73.3 \%$. The coefficient value of diversity was found to be greater in CoastalFemale cows than in Coastal Male cows so that selection efforts would be more effective in CoastalFemale cows compared to Male Coastal cows. Another factor that causes a decrease in body weight gain is that breeders are still conducting inbreeding marriages so that the negative impact on body weight gain Coastal cows that are maintained, this is in accordance with the opinion of [23] that one of the effects of inbreeding is the occurrence of inbreeding depression is characterized by a decrease in phenotypic averages, especially in traits that have high economic value. The results of this study are also supported by the opinion of [24] which states that cross-breeding in beef cattle results in a decrease in body weight of 2.5 to 5.0 $\mathrm{kg}$ per $10 \%$ increase in crossing.

\section{Amplification of Growth Hormone Gene (GH)}

Amplification of growth hormone gene fragments from DNA of coastal cow samples was 
carried out using two pairs of primers namely GH4 and GH5. The GH4F Primer pairs are GH4F 5'- GGA TGG CAG TGG AGG ATG AT -3 ', GH4R 5'- AGG TCT GCT TGA GGA TCT GC -3', and primary pair GH5F 5'- CTT CGG CCT CTC TGT CTC TC-3 ', and GH5R 5'- CTT CGG CCT CTC TGT CTC TC -3' with PCR stages starting from the initial denaturation process at a temperature of $95 \cdot \mathrm{C}$ for 5 minutes, $95 \cdot \mathrm{C}$ for 30 seconds, $58 \cdot \mathrm{C}$ for 30 seconds and $72 \cdot \mathrm{C}$ for 50 seconds performed as many as 34 repetitions or cycles continued $72 \cdot \mathrm{C}$ for 5 minutes. This PCR product was then visualized by electrophoresis at a voltage of 200 volts for 1 hour. This electrophoresis product was observed by using UV illuminator and DNA ladder (marker) as the standard size, the 599 bp GH4 PCR product was obtained, starting from position 1588 to 2187 in the [25].

Electrophoresis results of GH5 PCR products obtained along the $590 \mathrm{bp}$ starting from position 2105 to 2695 in the [25] and these results are in accordance with the expected fragment length.

The success rate of amplification for GH4 and GH5 was quite good. From the research experience in the laboratory, the success rate of amplification is determined by the level of anealing that we use at the time of the PCR because the level of anealing that is less precise, the amplification results will not be satisfactory. According to [26] the success of amplification is determined by the condition of the primary attachment of the target gene (genomic DNA) during the PCR process, the condition of the thermocycler machine and the interaction of the PCR mixed component.

\section{The Variance of Growth Gene Hormon}

Coastal cow growth hormone diversity carried out by PCR-RFLP method using 2 kinds of restriction enzymes, namely AluI and Eco 471. Based on the cutting site of each restriction enzyme used it can be stated that for GH4 fragments were restricted with AluI enzymes and GH5 fragments were restored with Eco enzyme 471.The results of restrictions on each enzyme in GH4 and GH5 fragments in Coastal cow obtained various kinds of genotypic combinations. Kinds and amounts of genotypes resulting from the cutting by restriction enzymes from each fragment of the Coastal cow GH gene can be seen in Table-4.

Table-4: Species and Amount of Genotype Produced From Restriction Using Alui and Eco 471 Coastal Cows Enzymes

\begin{tabular}{|l|l|l|l|l|}
\hline Cows Species & GH & Enzyme & The Number of Sample & Genotype and Ribbon Pattern \\
\hline \multirow{2}{*}{ Coastal } & GH4 & AluI & 141 & AA(112), BB(29) \\
\cline { 2 - 5 } & GH5 & Eco 471 & 141 & TT(73), TC(48), CC(20) \\
\hline
\end{tabular}

\section{Variance of GH4 Gene of Coastal Cow Genotype Frequency and GH4 Alel Gene of Coastal Cow}

The results of restriction / cutting with aluI enzymes against the GH4 gene in Coastal cow obtained two kinds of genotypes namely AA and BB genotypes.
The determination of this genotype is based on the difference in the position of the tape where in figure 5 the sample numbers 92 and 96 look different from the upper band position with a band length of $264 \mathrm{bp}$ and other samples below 264 bp with other samples and the genotype is BB while the other samples are AA-type.

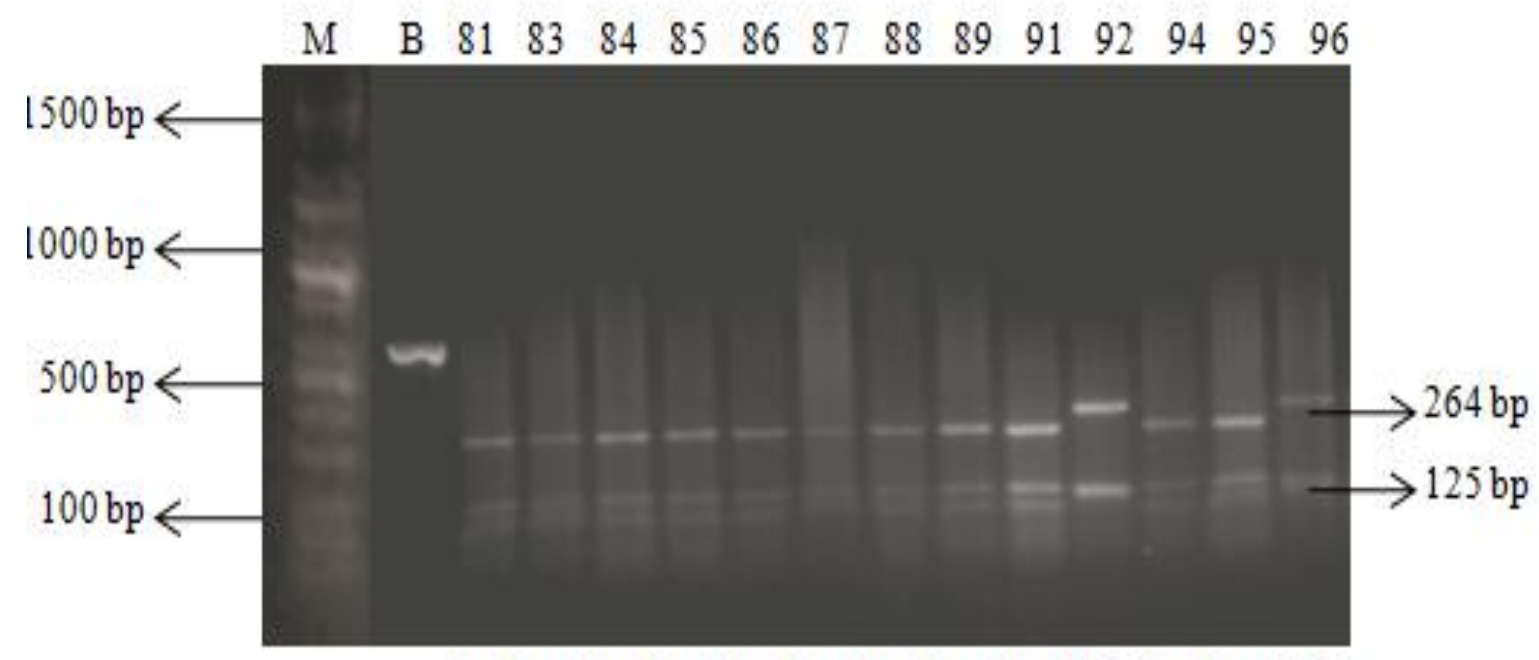

AA AA AA AA AA AA AA AA AA BB AA AA BB

Fig-1: The Result of Restriction on Fragment of GH4 Gene | Alui in Coastal Cows 
Mangku Mundana et al., Sch J Agric Vet Sci, Oct, 2020; 7(10): 219-230

NOTE: $\mathrm{M}=$ MARKER (LADDER 100 BP), NUMBERS 81-96 = SAMPLES (AA AND BB) $=$ GENOTYPE

In Figure-1, it can be stated that there are two types of genotypes namely AA and BB genotypes. The genotype formed was caused by the insertion of $\mathrm{C}$ in the GH sequence at position 1790 [7]. AluI enzyme had a cutting site at 5 '... A GC T ... 3' and the GH ACAGCTTGGT sequence on the sign (-) insertion $\mathrm{C}$ occured so that the sequence became ACAGCCTTGGT, if an insertion occured then the sequence was not interrupted. The GH4 gene fragment had a sequence length of 599 $\mathrm{bp}$, and based on the cutting site which was recognized by the AluI enzyme, the GH4 gene fragment is restricted using the AluI enzyme. AluI enzymes have a cutting site at 5 '... A GC T ... 3'. Based on the cutting site and after being applied to the $\mathrm{GH}$ gene sequence [25], five bands with $125 \mathrm{bp}, 77 \mathrm{bp}, 33 \mathrm{bp}, 264 \mathrm{bp}$ and 51 bp can be seen and for more details figure 6 . Furthermore, by amplifying the AluI enzyme in the GH4 gene fragment from PCR and visualizing with electrophoresis, 2 bands of the restriction result (Figure3 ) were obtained. Based on the results of cutting with the AluI restriction enzyme, the genotype and allele frequencies obtained are shown in Table-5.

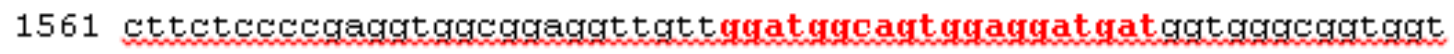 \\ $>>>>>>>>>>>>>>>>>>>$

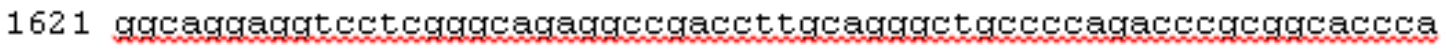

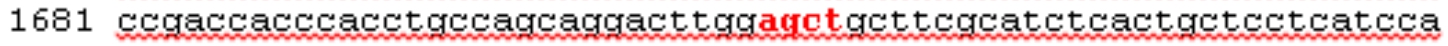

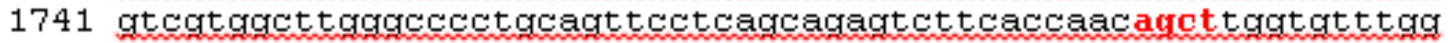

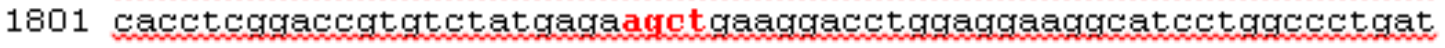

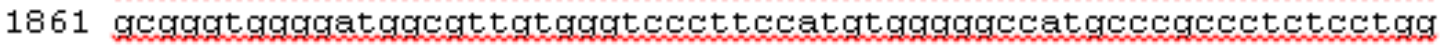

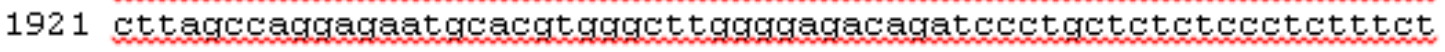

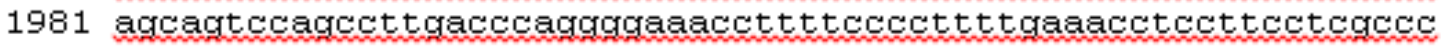

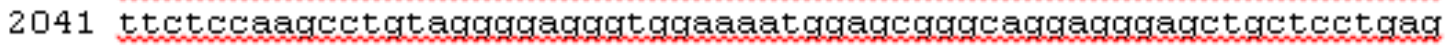

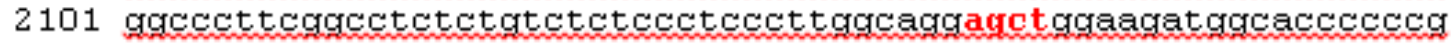 \\ 2161 ggetgggcagatcotcaagcagacctatgacaaatt gacacaaacatgegcagtgacga $<<<<<<<<<<<<<<<<<<<<$}

Fig-2: The Gh4 Gene Fragment Sequences and the Alui Enzyme Cutting Sitebased on the GH Gene Sequences in Genbank (Gordon Et Al. 1983).

Table 5: The Frequency of Genotypes and Alleles Produced From Restriction Results Using the Alui and Eco 471 Enzymes in Coastal Cows

\begin{tabular}{|l|l|l|l|l|}
\hline GH & Enzyme & $\begin{array}{l}\text { The Number } \\
\text { of sample }\end{array}$ & $\begin{array}{l}\text { Genotype Frequency/ Ribbon } \\
\text { Pattern Frequency }\end{array}$ & Alel Frequency \\
\hline GH4 & AluI & 141 & $\mathrm{AA}(0,79) ; \mathrm{BB}(0,21)$ & $\mathrm{A}(0,79) ; \mathrm{B}(0,21)$ \\
\hline GH5 & Eco 471 & 141 & $\mathrm{TT}(0,52) ; \mathrm{TC}(0,34)$ & $\mathrm{CC}(0,14) ; \mathrm{C}(0,31) ; \mathrm{T}(0,69)$ \\
\hline
\end{tabular}

In Table-5 it can be seen that in the Coastal cow with the GH4 gene with the AluI restriction enzyme did not produce $\mathrm{AB}$ genotype, the GH4 AluI gene had an AA genotype frequency of 0.79 and $\mathrm{BB}$ genotype of 0.21 and $\mathrm{AB}$ equal to zero (0.00). This causes the frequency of alleles obtained in Cattle Cow of allele was 0.79 and allele B was 0.21 . If the results of this study were compared with those of [4] with the same restriction enzyme, the results of the different allele frequencies obtained (0.992 and 0.008) this difference is likely the existence of differences in the position of the primary sequence (4th intron and 5 th exon). However, when compared with the results of [27] in Balinese cows on the island of Bali, the allele frequencies obtained were smaller in A allele and greater in allele B (1.00 and 0.00) and different from cattle Bali was on the island of Lombok where the allele frequencies obtained were 0.99 and 0.01 .

The Variance of GH5 Gene of Coastal Cow a. Genotype Frequency and GH5 gene alleles | Eco 471 in Coastal Cows

Diversity of Coastal cattle GH5 gene using Eco471 restriction enzyme can be seen in Figure-2. 


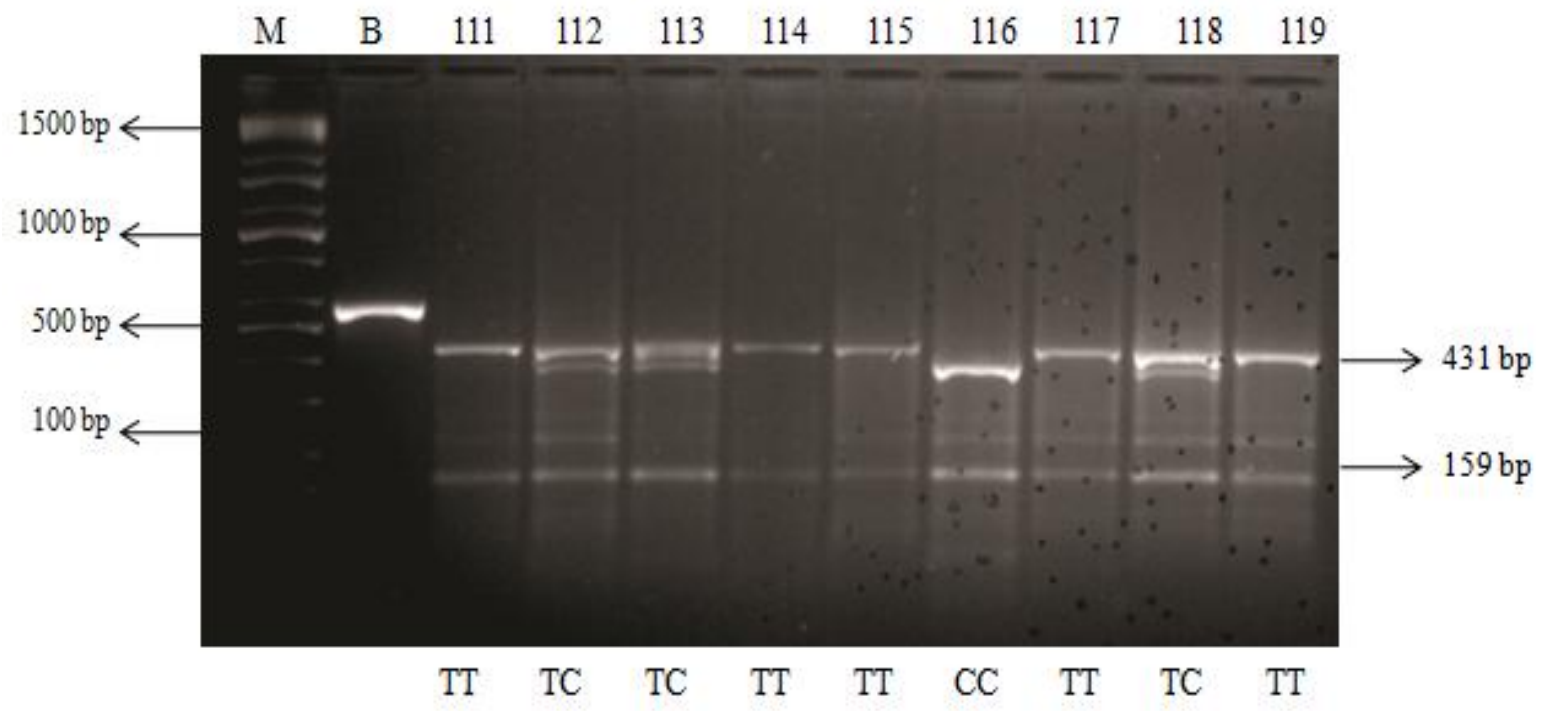

Figure-3: Result of Restriction of GH5 Gene Fragment Eco 471 in Coastal Cows

NOTE: $\mathrm{M}=$ MARKER, NUMBER 111 - $119=$ SAMPLE, $(\mathrm{TT}, \mathrm{TC}, \mathrm{CC})=$ GENOTYPE

Figure-3 shows the results of the restriction of the Eco471 enzyme in GH5 fragments in Coastal cows. There were 3 types of genotypes with 3 different banding patterns where TT genotypes with ribbon 2 , TC with 3 bands, and $\mathrm{CC} 3$ bands with different positions on the upper ribbons where the ribbon size less than 431 bp. At position 2647 in the $\mathrm{GH}$ sequence there was a transition from $\mathrm{T}$ to $\mathrm{C}$. The cutting site recognized by the Eco 471 enzyme was in the GG W C C where $\mathrm{W}$ is A or $\mathrm{T}$ and the GH TGGTTCTTAG gene sequence. The transition from $\mathrm{T}$ to $\mathrm{C}$ occurred at position 2647 so that the sequence changed to TGGTCCTTAG after being applied with the GH sequence [25] obtained 2 (two) bands measuring $431 \mathrm{bp}$ and $159 \mathrm{bp}$.

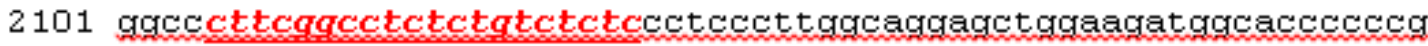 $>>>>>>>>>>>>>>>>>>$ \\ 2161 ggctgggcagatcctcaagcagacctatgacaaatt gacacaaacatgcgcagtgacga

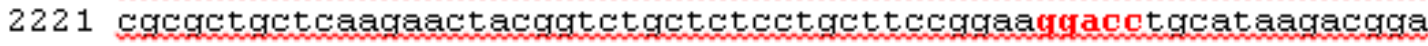

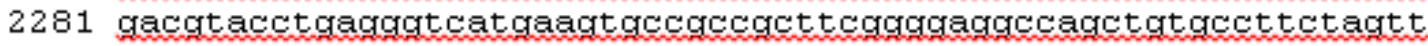

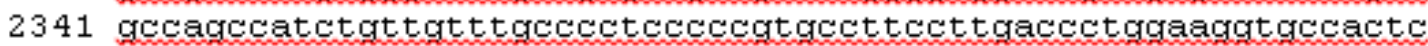 \\ 2401 ccactgtcetttcctaataaaat gaggaaat gcatcocattgtctgagtaggtgtcatt

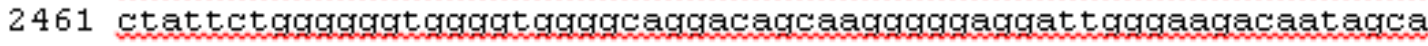

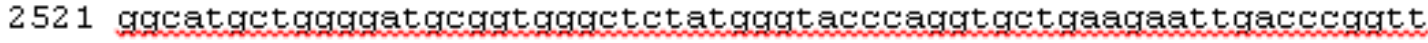

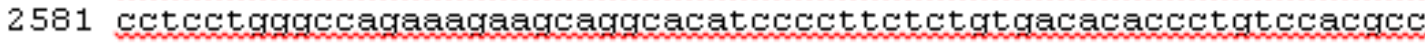 \\ 2641 cetggt tet agt ceagccccactcataggacactcatagctcaggagggctccgcett $<<<<<<<<<<<<<<<<<<<<$}

Fig-4: The GH5 Gene Fragment Sequence and Eco 471 Enzyme Cutting Site Are Based On the GH Gene Sequence in Genbank [25]

In this study obtained 72 genotypes of TT, TC 48 , and CC 20 samples. The frequency of each genotype can be seen in Table 5. In Table 5, the genotype and allele frequencies in Coastal cattle are found equally, namely TT genotype 0.52 , TC 0.34 and CC 0.14. Likewise, the allele frequency of Coastal cattle $\mathrm{T}$ allele frequency was 0.83 and $\mathrm{C}$ allele equals 0.00 . So with the restriction of the Eco471 enzyme in the GH5 gene, the polymorphic genotype was obtained.

\section{Estimation of Heterozygosity in Coastal Cows}

The results of the estimation analysis of observed heterozygosity (Ho) and expected heterozygosity (He), Coastal cow obtained the following results: Coastal cow has moderate observational heterozygosity (Ho) values, with a range of $0-0.34$ for all GH4 and GH5 genes. The observed heterozygosity $=0.00$ was obtained at GH4 AluI and GH5 Eco471 was found at 0.34. Likewise, the expectation heteriosigosity value in Coastal cattle which value is $0.32-0.34$. The expected heterosigosity value was obtained $=0.32$ at GH5 Eco471 and at GH4 AluI was 0.34 . If the observed heterosigosity value $=0.00$ means that among the population measured there has a very close genetic relationship. The observed heterosigosity value of 0.34 on GH5 Eco471 indicated 
the percentage of heterosigoty in the population of $34 \%$ in the medium category. When compared with the results of research [4] with the same enzyme, the AluI enzyme, the expected heterosigosity values were higher (0.0149), whereas with GH MspI the expected heterosigosity $\mathrm{GH}$ values were 0.3306 . The difference in the results of this study is likely due to differences in GH fragments used.

Estimating the value of heterozygosity is very important to know as a picture of genetic variability [28] polymophism of an allele and future population prospects [29]. The observed heterozygosity values (Ho) and expected heterozygosity $(\mathrm{He})$ fragments of the GH4 and GH5 genes are presented in Table 6. The low value of the heterozygosity that is equal to zero indicates that among the population measured it has a very close genetic relationship this is in accordance with [17] Estimating the value of heterozygosity is very important to know as a picture of genetic variability [28] polymophism of an allele and future population prospects [29]. The observed heterozygosity values (Ho) and expected heterozygosity (He) fragments of the GH4 and GH5 genes are presented in Table-6.

Table-6: Observation Heterozygosity (HO) and Expected Hetozygosity (HE) GH4 and GH5 Genes with Alui and Eco 471 Enzymes in Coastal Cattle

\begin{tabular}{|l|l|l|l|l|}
\hline GH & Enzyme & The number of sample & $\mathrm{H}_{\text {observed }} \mathrm{H}_{0}$ & $\mathrm{H}_{\text {Expected }} \mathrm{H}_{\mathrm{e}}$ \\
\hline GH4 & AluI & 141 & - & \\
\hline GH5 & Eco 471 & 141 & 0,34 & 0,32 \\
\hline
\end{tabular}

State that heterozygosity is the percentage of heterozygotes per individual or the average percentage of heterozygous individuals in the population. Calculation of the value of heterozygosity according to [17] is the value of heterozygosity that has values ranging from 0 (zero) to 1 (one), if heterozygosity is equal to 0 (zero), then among the population measured it has a very close genetic relationship and if the heterozygosity value is equal to 1 (one), then among the population measured there is no genetic relationship or genetic linkage at all.

The results of the estimation of observations of observed heterozygosity (Ho) and expected heterozygosity (He) of coastal cows had low observational heterozygosity (Ho) values that were equal to zero for all fragments of GH4 and GH5 genes. The low value of heterozygosity that was equal to zero indicates that among the population measured has a very close genetic relationship this is in accordance with the opinion of [17] If the results of this study were compared with the results of [30] research, the results of this study showed the same results in the GH1 gene and different in the $\mathrm{GH} 2$ and $\mathrm{GH} 3$ genes. Likewise, the expected heterosigosity values showed the same results in the GH1 gene fragment and different in the GH2 and GH3 gene fragments. The difference in the results of this study is likely due to differences in fragments and differences in the enzymes used.

Expected heterozygosity is an accurate predictor of genetic diversity in livestock populations because the calculations are based directly on the allele frequency [31] If the expected heterosigosity value is greater than the observed heterosigosity value $(\mathrm{He}>$ Ho), it indicates that the sample has a degree of endogamy (marriages in groups) as a result of an intensive selection process [32] and expectation heterosigosity $(\mathrm{He})$ showed that $\mathrm{HO}<\mathrm{He}$ in the GH4IMboII and GH5 gen genes AciI This shows the existence of an intensive selection process directly.

\section{Estimating the Value of PIC in Coastal Cow}

The results of estimating the value of PIC (Polymorphic Informative Content) on the PCR-RFLP identifier of the GH4 and GH5 gene fragments in Coastal cow are presented in Table-7.

Table-7: The Results of the Analysis of the Estimation of the Pic Value on the PCR-RFLP Identifier of the GH4 and GH5 Gene Fragments in Coastal Cows

\begin{tabular}{|l|l|l|l|l|}
\hline GH & Enzyme & The Number of Sample & PIC Value & Bolstein et al., (1980) [40] Category \\
\hline GH4 & AluI & 141 & 0,39 & Medium \\
\hline GH5 & Eco 471 & 141 & 0,51 & High \\
\hline
\end{tabular}

In Table-7 it can be seen that the PIC GH4AluI value obtained is a PIC value of 0.39 and GH5Eco 4710.51 . PIC values obtained were successively categorized as medium and high [19] Estimation of the value of PIC GH4-Alu-I and GH5-Eco 471 showedthat the PIC value obtained was polymorphic. Based on the estimation of the PIC value, it can be concluded that the GH4-Alu-I and GH5-Eco471 markers were effective. If the results of this study are compared with the results of [27] on Balinese cows in Bali and those on Lombok
Island, GH4-Alu-I showedthe same results as GH Alu-I of Balinese cows on the island of Lombok, namely are in the same category while the PIC values.

\section{The Relationship between Variance of GH4 and GH5 Genes with Increased Weight of Coastal Cow Bodies}

In accordance with the statistical model used that was $\mathrm{Yij}=+\alpha \mathrm{i}+\beta \mathrm{j}+\mathrm{Gk}+$ Eijk, the relationship between the diversity of the GH4 and GH5 genes with 
body weight gain was assessed in terms of the influence of several factors, namely the influence of sex (sex), age, and genetic influences. The results of data processing using the SAS program from the influence of sex, age, and AluI enzymes obtained the calculated $\mathrm{F}$ values were $1.22,1.83$, and 1.50 and when compared with the F Table value of 2.1 then Fhit. $<F$ tab. So the influence of sex factors, age and type of AluI restriction enzyme showed different results were not significant. Likewise, the results of the influence of sex, age, and other types of restriction enzymes.
Based on Table- 8 it is found that from the results of GLM analysis body weight gain and its relationship to the genotype of the GH4 and Gh5 genes in Coastal cow obtained Fcount values smaller than FTable (2.1) and (1.08) in GH4 | AluI and GH5 | Eco471. Probabilities obtained from the two identifiers indicate a value greater than 0.05 (probability). Based on this, it can be concluded that there is no relationship of diversity between the GH4 | AluI and GH5 | Eco471 genes with body weight gain in Coastal cows.

Table-8: Results of General Lineage Analysis of Body Weight Gain (KG) and Its Relationship to the GH4 and GH5 Genes in Coastal Cattle

\begin{tabular}{|l|l|l|l|l|}
\hline \multirow{2}{*}{ The chacteristics of PCR-RFLP } & \multicolumn{2}{|l|}{ Linear Analysis Results } & \multirow{2}{*}{ Decision } \\
\cline { 2 - 5 } & Fcount & Ftable & Sig & \\
\hline GH4|AluI & 1,50 & 2,10 & 0,05 & tn \\
\hline GH5|Eco471 & 0,41 & 1,94 & 0,05 & tn \\
\hline
\end{tabular}

Description; $\mathrm{tn}=$ not real different $*=$ real different

The results of this study in which the relationship between genotype and body weight gain in Coastal cow is not significantly different (non signifficant) except for GH4 | MboII, then these results are in accordance with the opinion expressed by [24, $29,33,34]$ that the nature of production is a trait that is controlled by many genes (polygenes) and environmental influences are very large. Some genes that affect life weight, such as; GHR, Insulin-Like Growth Factor-I, and the hormone prolactin are considered as markers to determine the quantitative nature of livestock [35] Genetically added Coastal cow respond well to changes in maintenance patterns [36].

Some reports state that the GH gene is an indicator for the characteristics of meat production, so it can be used to improve cow genetic among them; genotype has a strong correlation with body weight of dairy cattle in Grati [5]. genotype had a significant influence on growth performance and weight gain of Ongole crossbred cattle [37] there are indications of four SNP BGH genes in the area The promoter is related to the growth and quality of the Hanwoo carcass [41], the presence of SNP in the '-120' position of the promoter area was related to body weight of 3 months and carcass weight in Hanwoo cattle [38]. Other results also report that there was no strong relationship between genotype and body weight, chest thickness and body length in Coastal cattle [4] and there was no significant effect between GH polymorphism with body weight and meat production in Zavot cattle in Turkey [35].

\section{CONCLUSION}

1. The diversity of body weight gain of female Coastal cow was greater than Male Coastal cattle.

2. Diversity of Coastal cow growth hormone genes found in GH4 | AluI and GH5 | Eco471.
3. There was no significant relationship ( $\mathrm{P}>0.05)$ between GH4 and GH5 growth hormone genes with body weight gain in Coastal cattle.

\section{REFERENCE}

1. Saladin R. Penampilan Sifat-sifat Produksi dan Reproduksi Sapi Lokal Pesisir Selatan di Propinsi Sumatera Barat. Disertasi. Fakultas Pascasarjana IPB. Bogor. 1983.

2. Khasrat. Pertumbuhan karakteristik karkas dan kualitas daging sapi Pesisir yang dipelihara secara intensif pada periode waktu yang berbeda. Disertasi Program Pascasarjana Universitas Andalas. 2006.

3. Sutarno. Candidate gene marker for production traits in beef cattle. In: Veterinary Biology. Perth: Murdoch University. 1998.

4. Jakaria J, Duryadi D, Noor RR, Tappa B, Martojo H. Evaluasi keragaman genetik gen hormon pertumbuhan $(\mathrm{GH})$ pada sapi Pesisir Sumatera Barat menggunakan penciri PCR-RFLP. Media Peternakan. 2007 Apr;30(1):151776.

5. Maylinda S. Genetic Polymorphism of Growth Hormone Locus and Its Association with Body Weight in Grati Dairy Cows. International Journal for Biotechnology and Moleculer Biology Research. 2011; 2(7):117-120.

6. Jakaria. Keragaman genetik gen hormone pertumbuhan pada sapi Pesisir Sumatera Barat. Disertasi Sekolah Pasca Sarjana Institut Pertanian Bogor. 2008.

7. Yurnalis. Polimorfisme Gen Hormon Pertumbuhan Pada Sapi Pesisir Sumatera Barat. Disertasi Program Pascasarjana Universitas Andalas. 2013

8. Unanian MM, Barreto CC, Freitas AR, Cordeiro CM, Josahkian LA. Associations between growth hormone gene polymorphism and weight traits in Nellore bovines. Revista Brasileira de Zootecnia. 2000 Oct;29(5):1380-6. 
9. Garcia MD, Thomas MG, Silver GA, Hallford DM, Enns RM. Relationship of the growth hormone $(\mathrm{GH})$ MspI RFLP to pituitary responseveness to GHRH and growth trait in Angus and Brangus Bulls. Plant \& Animal Genomes XI Conference. San Deigo, CA. 2003.

10. Di Stasio L, Destefanis G, Brugiapaglia A, Albera A, Rolando A. Polymorphism of the GHR gene in cattle and relationships with meat production and quality. Animal Genetics. 2005 Apr;36(2):138-40.

11. Bartke A. Effects of Growth Hormone Review on Male Reproductive Functions. Journal of andrology. 2000 Mar 4;21(2):181-8.

12. Thomas MG, Silver GA, Enns RM. Relations of DNA Polymorphisms in Growth Hormone (GH) to Growth and Carcass Traits Observed in a Population of Brangus Bulls with a Larger Number of Series. Int. Plant and Animal Genome XIV, 2006: P526.

13. Curi RA, Palmieri DA, Suguisawa L, Oliveira HN, Silveira AC, Lopes CR. Growth and carcass traits associated with GH1/Alu I and POU1F1/Hinf I gene polymorphisms in Zebu and crossbred beef cattle. Genetics and Molecular Biology. 2006;29(1):56-61.

14. Steel RGD, Torie JH, Dickey DH. Principles and Procedures of Statistics: A Biometrical Approach, $3^{\text {rd }}$ Ed. McGraw Hill Inc. Singapore. 1997.

15. Steel RGD, dan Torrie JH. Prinsip dan Prosedur Statistika. Penterjemah Bambang Sumantri. Gramedia Pustaka, Jakarta. 1995.

16. Nei M, Kumar S. Molecular Evolutionary Genetics. Columbia University Press. New York. 2000.

17. Nei M. Molecular Evolutionary Genetics. Columbia University Press. New York. 1987.

18. Weir BS. Genetic Data Analysis: Method for Discrete Population Genetic Data. Second ed. Sinauer Associates. Sunderland, MA USA. 1996.

19. Botstein D, White RL, Skolnick M, Davis RW. Construction of a genetic linkage map in man using restriction fragment length polymorphisms. American journal of human genetics. 1980 May;32(3):314-331.

20. Gaspersz V. Teknik Analisis dalam Penelitian Percobaan. Penerbit Tarsito, Bandung. 2006.

21. Wirdahayati RB, Bamualim A. Produktivitas ternak sapi lokal pesisir dan daya dukung lahan penggembalaan di kabupaten Pesisir Selatan Sumatera Barat. InProsiding Seminar Nasional Teknologi Peternakan dan Veteriner. Pusat Penelitian dan Pengembangan Peternakan. Bogor: hlm 2007 (pp. 122-131).

22. Bamualim AM, dan Wirdahayati RB. Peranteknologidalampengembangansapilokal.

Hlm. 56-64. Prosiding seminar Nasional Revitalisasi Potensi Lokaluntuk Meujudkan Swasembada Daging $2010 \quad$ Dalam KerangkaPembangunan
Berkelanjutandan Peningkatan Kesejahteraan Masyarakat, Padang, 11-12 September 2006.

23. Mikema D. Dasar Genetik dalam Pembudidayaan Ternak. Jakarta: Bharata Karya Aksara. 1987.

24. Warwick EJ, Astutikdan JM, Hardjosubroto W. Pemuliaan Ternak. Gadjah Mada University Press. Yogyakarta. 1983.

25. Gordon DF, Quick DP, Erwin CR, Donelson JE, Maurer RA. Nucleotide sequence of the bovine growth hormone chromosomal gene. Molecular and cellular endocrinology. 1983 Nov 1;33(1):8195.

26. Palumbi SR. Nucleic acids II: The polymerase chain reaction. In: Hillis DM, Moritz Dan C, Mable BK. (Editor). Molecular Systematics. $2^{\text {nd }}$ Edition. Sinauer Associates. Inc., Massachusetts USA. 1996.

27. Jakaria J, Noor RR. Analysis on Alu-I growth hormone (GHAlu-I) gene in Bali cattle. Journal of Indonesian Tropical Animal Agriculture. 2011;36(2):77-82

28. Marson EP, Ferraz JB, Meirelles FV, Balieiro JC, Eler JP, Figuerido LG, Mourão GB. Genetic characterization of European-Zebu composite bovine using RFLP markers. Genet. Mol. Res. 2005 Sep 30;4(3):496-505.

29. Falconer DS, Mackay TFC. Introduction to Quantitative Genetic. $4^{\text {th }}$ Ed. Essex, England: Longman Group Ltd. 1996.

30. Suhada H. Keragaman genetik gen hormone pertumbuhan dan hubungannya dengan pertambahan bobotba dan pada sapi Simmental. Disertasi. Program Studi lmu Peternakan Program Doktor Fakultas Peternakan Universitas Andalas. 2016.

31. Moioli B, Napolitano F, Catillo G. Genetic diversity between Piedmontese, Maremmana, and Podolica cattle breeds. Journal of Heredity. 2004 May 1;95(3):250-6.

32. Machado MA, Schuster I, Martinez ML, Campos AL. Genetic diversity of four cattle breeds using microsatellite markers. Revista Brasileira de zootecnia. 2003 Feb;32(1):93-8.

33. Bourdon RM. Understanding Animal Breeding. Prentice-Hallo, Inc. New Jersey. 1997.

34. Noor RR. Genetika Ternak. Penebar Swadaya, Jakarta. 2004.

35. Akcay A, Akyüz B, Bayram D. Determination of the AluI polymorphism effect of bovine growth hormone gene on carcass traits in Zavot cattle with analysis of covariance. Turkish Journal of Veterinary and Animal Sciences. 2015 Jan 27;39(1):16-22.

36. Munir RMB, Ridwan SN, Asmak, dan Zulrasdi. Sistem Usaha Tani Terpadu Pangan dan Ternak Spesifik Lokasi (Crop Livestock Sistem). Laporan Tahunan. Balai Pengkajian Teknologi Pertanian Sumatera Barat, Sukarami. 2003.

37. Paputungan U, Hakim L, Ciptadi G, Lapian HF. Production of Progenies by Different Growth 
Hormone Genotypes (GH-MspI) of Their Parents Using PCR-RFLP in Ongole-crossbred Cattle. Animal Production. 2013;15(1):53-61.

38. Kim JJ, Farnir F, Savell J, Taylor JF. Detection of quantitative trait loci for growth and beef carcass fatness traits in a cross between Bos taurus (Angus) and Bos indicus (Brahman) cattle. Journal of Animal Science. 2003 Aug 1;81(8):1933-42.

39. Cowan LD, Bodensteiner JB, Leviton A, Doherty L. Prevalence of the epilepsies in children and adolescents. Epilepsia. 1989 Feb;30(1):94-106.
40. Botstein D, White RL, Skolnick M, Davis RW. Construction of a genetic linkage map in man using restriction fragment length polymorphisms. American journal of human genetics. 1980 May;32(3):314.

41. Lee JM. Validity of consumer-based physical activity monitors and calibration of smartphone for prediction of physical activity energy expenditure. 2013. 